\title{
Synthesis and Characterization of ZnO Thin Layers using Sol-Gel Spin Coating Method
}

\author{
1Sukainil Ahzan, ${ }^{2}$ Darminto, ${ }^{3}$ Ferry Anggoro Ardy Nugroho, ${ }^{*}$ Saiful Prayogi \\ ${ }^{1}$ Faculty of Applied Science and Engineering, Universitas Pendidikan Mandalika, Jl. Pemuda No. 59A, \\ Mataram 83126, Indonesia. \\ 2Faculty of Mathematics and Science, Institut Teknologi Sepuluh Nopember (ITS), Jl. Raya ITS, \\ Surabaya 60111, Indonesia. \\ 2Departmet of Physics and Astronomy, Vrije Universiteit Amsterdam, De Boelelaan 1081, 1081 HV
} Amsterdam, The Netherlands.

*Corresponding Author e-mail: saifulprayogi@ikipmataram.ac.id

Received: May 2021; Revised: June 2021; Published: July 2021

\begin{abstract}
The potential of thin layer in many applications has led to research on the development of many new materials and their fabrication methods. This study aimed to synthesize a thin layer of $\mathrm{ZnO}$ using the facile and low-cost sol-gel spin coating method. The $\mathrm{ZnO}$ thin layer is deposited on a glass substrate and analyzed to observe the influence of the deposition variables such as heating and rotation speed, and its aging. The characterization methods include the identification of the formed phase using XRay Diffractometer (XRD), and the microstructure and elemental composition using Scanning Electron Microscopy (SEM) coupled with EDS (Energy Dispersive Spectrometer). The study shows that a thin layer of $\mathrm{ZnO}$ is successfully deposited on a glass substrate by heat treatment at temperatures of $300^{\circ} \mathrm{C}$ and $500{ }^{\circ} \mathrm{C}$. Furthermore, XRD reveals that higher heating temperatures result in higher diffraction peak intensity. At a heating temperature of $300{ }^{\circ} \mathrm{C}$ crystals are formed but are not yet perfectly oriented, while they are at $500^{\circ} \mathrm{C}$. On the other hand, higher spin coating rotation speed gives rise to lower intensity of diffraction peak. The $\mathrm{ZnO}$ crystallization is easier to form in the coating process with a lower rotation $(1500 \mathrm{rpm})$. Interestingly, the thin layer is stable over time where there is no significant change in each sample, both in terms of intensity and width of the $\mathrm{ZnO}$ crystal peak. The results indicate that gel precursor aged less than two days can form $\mathrm{ZnO}$ crystals. Finally, SEM results show that the surface morphology of the $\mathrm{ZnO}$ layer heated at $500{ }^{\circ} \mathrm{C}$ has an average grain size of 300 $\mathrm{nm}$. Based on the cross-sectional results of SEM shows that the higher the coating rotation speed has resulted the thinner of the $\mathrm{ZnO}$ layer, where the thickness of the resulting layer is on order $>5 \mu \mathrm{m}$.
\end{abstract}

Keywords: synthesis; characterization; $\mathrm{ZnO}$ thin layer; sol-gel spin coating

How to Cite: Ahzan, S., Darminto, D., Nugroho, F. A. A., \& Prayogi, S. (2021). Synthesis and Characterization of ZnO Thin Layers using Sol-Gel Spin Coating Method. Jurnal Penelitian Dan Pengkajian Ilmu Pendidikan: E-Saintika, 5(2), 182-194. https://doi.org/10.36312/esaintika.v5i2.506

\section{INTRODUCTION}

In recent decades, as the demand for energy continues to increase, there has been tremendous interest in developing renewable energy sources and environmentally friendly technological device systems (Matsuda \& Kawamura, 2016), some of which include fuel-cells, solar-cells, supercapacitors, and efficient batteries (Tan et al., 2021). In accordance with the interest in many fields of application, thin layers of several materials have been developed by the sol-gel method (Soo et al., 2013a, 2013b). Since 
being introduced by Groove in 1852, thin layer technology has undergone many developments in terms of manufacturing methods, materials used, and applications (Greene, 2017). In the thin layer processing technique, the material commonly used is metal (Jittiarporn et al., 2017; Mironyuk et al., 2020; Shi et al., 2020; Tan et al., 2020), organic, inorganic, and hybrid organic-inorganic (Kawamura et al., 2010; Nisticò et al., 2017; Takahashi, 2018; Takahashi et al., 2014).

The advancement of thin films by the sol-gel method for various applications is highly dependent on the material used. In fuel-cell applications, for example, PDDA films and microparticles of $\mathrm{PhSiO}_{3 / 2}$ succeeded in increasing proton conductivity to achieve a stable proton supply (Daiko et al., 2008). Likewise, Pt/ $\mathrm{TiO}_{2}$ was demonstrated as an electrocatalyst for fuel-cell electrolyte membrane applications (Nbelayim et al., 2020). The performance of a lightweight, high-capacity battery is developed from the synthesis of $\mathrm{Li} / \mathrm{Ti}$ double alkoxides in a $\mathrm{Li}_{4} \mathrm{Ti}_{5} \mathrm{O}_{12}$ thin film (Mosa \& Aparicio, 2020), and $\mathrm{LiF} / \mathrm{FeF}_{2}$ in the form of $\mathrm{Li}^{2} .5 \mathrm{FeF}_{3}$ (Kim et al., 2012; Tawa et al., 2019). Formation of superhydrophobic/superhydrophilic layers in film fabrication including surface design and film coating using $\mathrm{Al}_{2} \mathrm{O}_{3}, \mathrm{ZrO}_{2}$, and $\mathrm{TiO}_{2}$ materials (Tadanaga et al., 2004). In addition, the development of thin films by the sol-gel method is used in the extraction technology of waste disposal, especially heavy metal adsorbents , such as electro-spinned flexible $\mathrm{Fe}_{3} \mathrm{O}_{4}$ fibers (Shi et al., 2020) and yttriastabilized $\mathrm{ZrO}_{2}$ membranes (Qin et al., 2020). The most extensively researched is the application of thin layers as solar-cells (dye-sensitized solar cells, DSSC) (Abd-Ellah et al., 2016; Nbelayim et al., 2017, 2018, 2020; Tan et al., 2017; Toe et al., 2020), from zinc oxide material (ZnO) (Khan et al., 2017; Muchuweni et al., 2017; Prasada Rao et al., 2010).

Sol-gel coating techniques commonly used include spray coating, dip coating, roll coating, and spin coating (Tan et al., 2021). Among these, spin-coating method is the most frequently used (Khan et al., 2017). This method combines simple physical and chemical methods and has several advantages compared to other methods, for instance being cost-efficient with relatively simple setup, and excellent control over the thickness (through parameters of time, rotational speed, and viscosity of the solution) and the homogeneity of the layer (Cheng et al., 2003).

Among thin film-forming materials, zinc oxide $(\mathrm{ZnO})$ is the most extensively studied because it is one of the transparent semi-conductive oxides (Zou et al., 2007) with a relatively high exciton binding energy $(60 \mathrm{mEV})$ and a wide band gap around of 3.2 to $3.4 \mathrm{eV}$ (Rwenyagila et al., 2014; Sivaramakrishnan \& Alford, 2010; ValverdeAguilar \& Manríquez Zepeda, 2015). These advantages of optical and electrical properties allow $\mathrm{ZnO}$ to be applied as optical waveguides, optoelectronic devices (Çopuroğlu et al., 2009; Khan et al., 2017; Rwenyagila et al., 2014), piezoelectricity, conductive gas sensors, transparent conductive electrodes, photocatalysts and DSSC (Djurišić et al., 2010). One of the exciting properties of $\mathrm{ZnO}$ is its crystal formation process that occurs at temperatures under $400{ }^{\circ} \mathrm{C}$. This phenomenon depends on the type of deposition and the solvent used. Previous studies showed that crystalline $\mathrm{ZnO}$ was formed using ethylene glycol and glycerol as a solvent at a heating temperature of $200{ }^{\circ} \mathrm{C}$ (Torres Delgado et al., 2009). Heating at temperatures below $300^{\circ} \mathrm{C}$ is an early stage of heating, where the crystal structure has been formed but has not been oriented perfectly. Furthermore, with higher heating at $400{ }^{\circ} \mathrm{C}$ and $500{ }^{\circ} \mathrm{C}$, the ZnO crystal structure will be perfectly oriented (Raoufi \& Raoufi, 2009). Another attractive property of $\mathrm{ZnO}$ to observe is aging. Aging is the storage of sol-gel for a certain time 
before being used as a coating material. The aging process affects the physical, electrical, and optical properties of the $\mathrm{ZnO}$ thin film (Xu et al., 2009).

Literature surveys reveal that reports on the properties of $\mathrm{ZnO}$ thin films deposited by the sol-gel technique is lacking (Khan et al., 2017). Here, we develop a thin layer of $\mathrm{ZnO}$ material by the sol-gel spin coating method and assess its crystallization properties and morphology. The variables that are the focus of this study include heat treatment, rotation speed, and aging

\section{METHOD}

A thin layer was deposited on a glass substrate of $5 \times 10 \mathrm{~mm}^{2}$ using a sol-gel method using zinc acetate dehydrate $\left\{\mathrm{Zn}\left(\mathrm{CH}_{3} \mathrm{COO}\right)_{2} .2 \mathrm{H}_{2} \mathrm{O}\right\}$ powder $(\mathrm{M}: 219.49$ $\mathrm{g} / \mathrm{mol}, 99 \%$ Merck, Germany) with a molar ratio of 1:1 MEA:ZnAc. Ethanol $\left(\mathrm{C}_{2} \mathrm{H}_{6} \mathrm{O}\right)$ (99\% technical, Merck) was used as solvent and ethanolamine (MEA: $\mathrm{C}_{2} \mathrm{H}_{7} \mathrm{NO}$ ) as stabilizer, each with a purity of $99 \%$. The solution was prepared by magnetic stirring at $\pm 70{ }^{\circ} \mathrm{C}$ for 30 minutes. ZnAc was rather difficult to dissolve in ethanol. Therefore the dissolution process must be accompanied by heating, which was carried out on a hot plate with a temperature range of 80 to $100{ }^{\circ} \mathrm{C}$. This was followed by the addition of MEA. After the heating process for 30 to 40 minutes, the solution was then allowed to stand at room temperature to form a gel. The gel was the divided into five parts and each was aged for $0,10,24,48$ and 72 hours, in air with a temperature of $\pm 25^{\circ} \mathrm{C}$ and humidity of $70 \pm 5 \%$.

The thermal behavior of $\mathrm{ZnO}$ gel was tested using Differential Thermal Analysis (DTA) and Thermogravimetric Analysis (TGA). This analysis aimed to observe changes in energy and mass as function of temperature. The DTA/TGA analysis results are used as a reference in determining the temperature at which the phase transformation occurs.

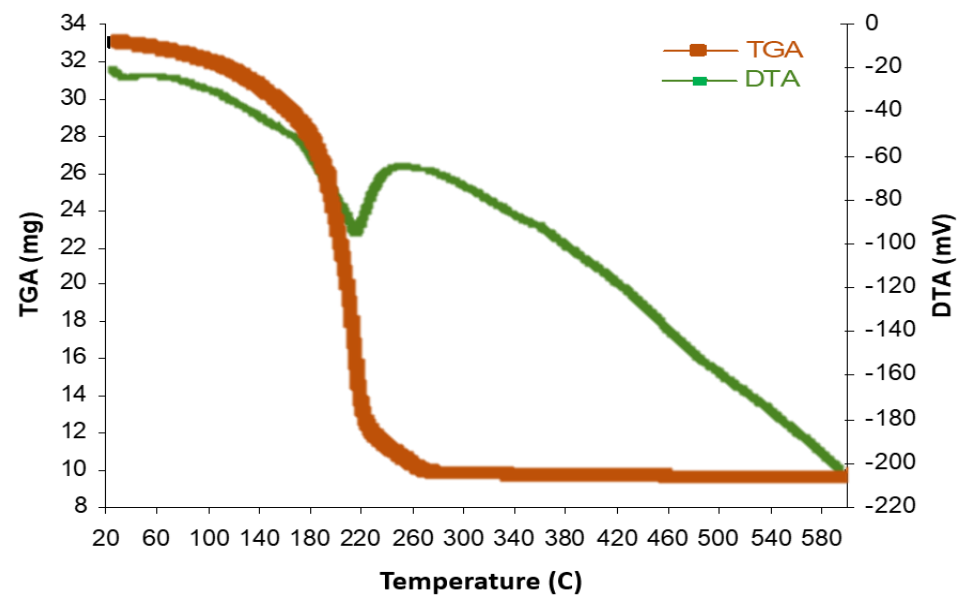

Figure 1. DTA-TGA test results of $\mathrm{ZnO}$ thin film deposited by spin coat sol-gel.

Based on the results of the TGA (Fig. 1), it can be seen that there is $90 \%$ decrease in mass up to a temperature of $280^{\circ} \mathrm{C}$, after which there is no further decrease in mass. This decrease in mass is followed by energy release or endothermic (DTA Graph in Fig. 1). Based on the DTA and TGA graphs, it is estimated that the change of $\mathrm{ZnO}+$ $\mathrm{H}_{2} \mathrm{O}$ into $\mathrm{ZnO}$ crystals occurs on heating above $280{ }^{\circ} \mathrm{C}$, so that the $\mathrm{ZnO}$ layer preheating process can be carried out at a temperature of $300^{\circ} \mathrm{C}$.

The deposition of the thin layer on a glass substrate with spin coating was also carried out at 1500, 2000, and $2500 \mathrm{rpm}$ variations. A thin layer of $\mathrm{ZnO}$ was heated 
using a furnace. The heating process was carried out in 3 stages. The first heating for 1 hour at a temperature of $100{ }^{\circ} \mathrm{C}$ (calcination) aimed to gradually remove the water content and residual solvent in the layer. The second heating at $300{ }^{\circ} \mathrm{C}$, where the temperature was slowly increased from room temperature to $300{ }^{\circ} \mathrm{C}$ for 5 hours, was held for 6 minutes. This stage was a pre-heating stage that functioned to remove solvents from ethanol, water, MEA, and facilitated $\mathrm{ZnOH}$ conversion to $\mathrm{ZnO}$. The next stage was post-heating or final heating at a temperature of $500{ }^{\circ} \mathrm{C}$. Like the pre-heating process, the temperature rise was set slowly from room temperature to $500{ }^{\circ} \mathrm{C}$ in 10 hours, then held for 10 minutes. This post-heating functioned to form $\mathrm{ZnO}$ particles with uniform crystal orientation and eliminate the pores.

The characterization of the coating results included identification of the formed phase using X-ray Diffractometer (XRD) with the help of a search match and refinement program using Rietica software with the comparison is standard data (CPI ZnO 1011259), layer microstructure, and elemental composition observed by Scanning Electron Microscopy (SEM) coupled with EDS (Energy Dispersive Spectrometer).

\section{RESULTS AND DISCUSSION}

\section{Effect of heating on the $\mathrm{ZnO}$ crystal layer}

The X-ray diffraction pattern of the $\mathrm{ZnO}$ layer deposited at $2000 \mathrm{rpm}$ at various heating temperature and aged for 24 hours is shown in Figure 2.

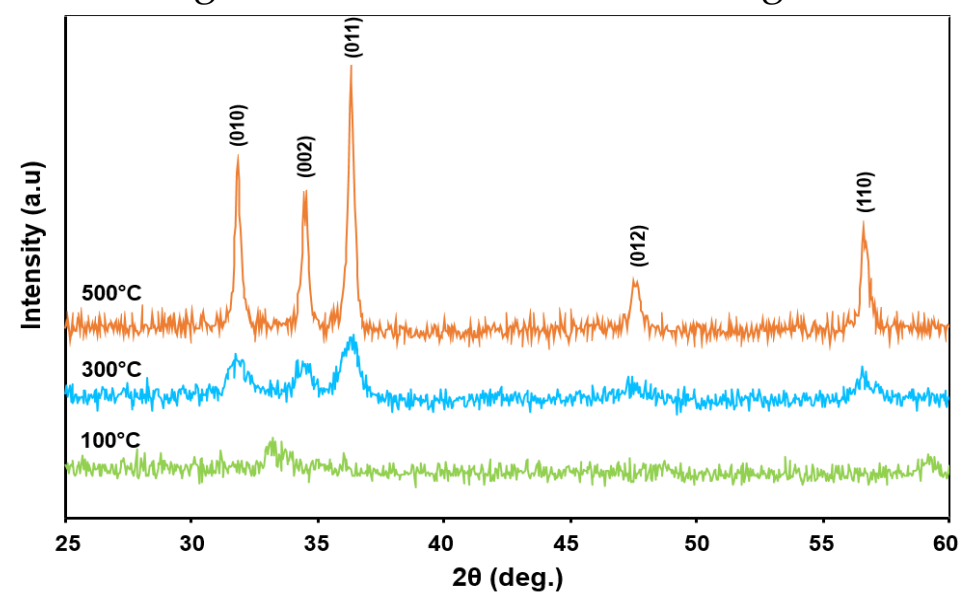

Figure 2. XRD pattern of $\mathrm{ZnO}$ layer with the variation of heating temperature

Based on Figure 2, it can be seen that the layer heated at a temperature of $100{ }^{\circ} \mathrm{C}$ forms two peaks at an angle of $33.15^{\circ}$ and $59.30^{\circ}$. These peaks correspond to zinc propianate $\left(\mathrm{C}_{6} \mathrm{H}_{10} \mathrm{O}_{4} \mathrm{Zn}\right)$ phase and zinc salicylate dihydrete $\left\{\left(\mathrm{C}_{6} \mathrm{H}_{10} \mathrm{O}_{6} \mathrm{Zn}\right) \cdot 2 \mathrm{H}_{2} \mathrm{O}\right\}$ phase, respectively. These peaks clearly originate from the solvents on the layer.

At a heating temperature of $300{ }^{\circ} \mathrm{C}$ crystals are formed but are not yet perfectly oriented. At $500{ }^{\circ} \mathrm{C}$, the $\mathrm{ZnO}$ crystals are perfectly oriented. This is consistent with the results of DTA-TGA (cf. Fig. 1) in that the formation of $\mathrm{ZnO}$ occurs above $280^{\circ} \mathrm{C}$. With the help of the Rietica program, hexagonal $\mathrm{ZnO}$ has been formed with lattice parameters for a temperature of $300^{\circ} \mathrm{C}(a=3,245 \AA, c=5,209 \AA)$ and a temperature of $500^{\circ} \mathrm{C}(a=3,249 \AA, c=5,205 \AA)$. In the range of $2 \theta$ of $25^{\circ}$ to $60^{\circ}$, crystal plane peaks are formed, indicating that the layer obtained is polycrystalline.

Pre- and post-heating affect the $\mathrm{ZnO}$ layer in the form of solvent evaporation and reaction material decomposition. At low pre-heating temperature $\left(<300^{\circ} \mathrm{C}\right)$, the $(100)$, (002), and (101) diffraction peaks appeared with random preferential growth. This 
happens because at this temperature, the reagents have completely evaporated, and the thermal decomposition of the precursors has not yet occurred. Still, they occur at post-heating temperatures above $500{ }^{\circ} \mathrm{C}$ (Suwanboon et al., 2008). The increase in the intensity of the diffraction peak at higher temperatures is due to greater energy available to increase the movement of atoms, which increases the quality and crystallization of the layer (Mandal et al., 2008).

\section{Effect of spin coating speed on $\mathrm{ZnO}$ layer}

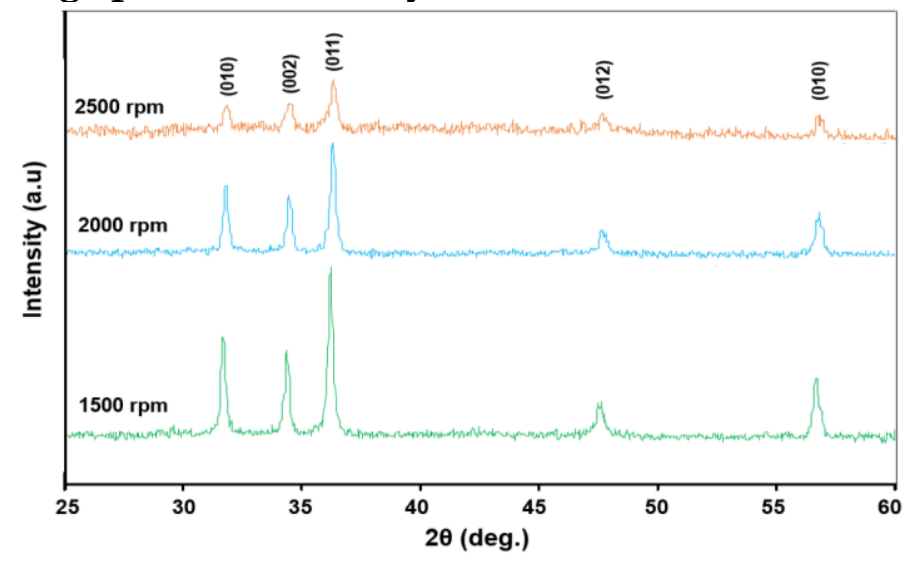

Figure 3. The XRD pattern of the $\mathrm{ZnO}$ layer with variations in spin coat rotational speed.

Figure 3 shows $\mathrm{XRD}$ results for $\mathrm{ZnO}$ layers made with variations in rotational speed of 1500, 2000, and $2500 \mathrm{rpm}$. The XRD peaks of the three samples show a decrease in intensity as rotation speed increases. This happens because $\mathrm{ZnO}$ crystallization is easier to form in the coating process with a lower rotation (1500 rpm).

Effect of aging on $\mathrm{ZnO}$ crystal layer

The XRD pattern of the synthesized $\mathrm{ZnO}$ layer with variations in aging of the precursor gel is presented in Figure 4.

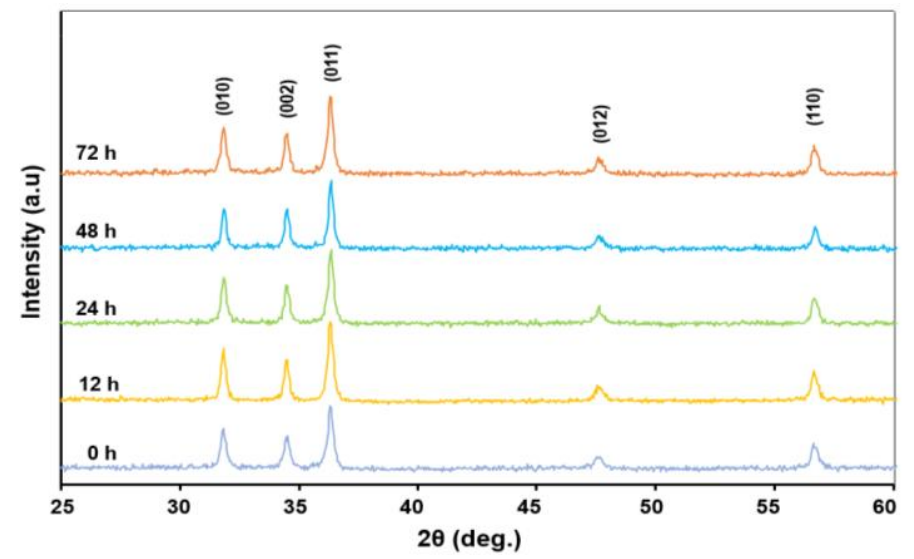

Figure 4. XRD pattern of deposited $\mathrm{ZnO}$ layer with an aging variation.

Based on Figure 4, there is no significant change in each sample, both in terms of intensity and width of the $\mathrm{ZnO}$ crystal peak. These results indicate that gel precursor aged less than two days can form $\mathrm{ZnO}$ crystals. The results of another study reported that after aging for seven days, the peak intensity (002) of $\mathrm{ZnO}$ increased compared to samples aged for up to two days (Maldonado et al., 2010). This may occur because 
aging can cause further condensation of active groups and $\mathrm{ZnO}$ aggregation in solution and cause significant growth at peak intensity (002) of ZnO (Fathollahi \& Amini, 2001).

\section{Surface morphology of $\mathrm{ZnO}$ thin layer}

SEM photos of the $\mathrm{ZnO}$ layer surface heated at 100,300 , and $500{ }^{\circ} \mathrm{C}$, respectively, are presented in Figure 5.

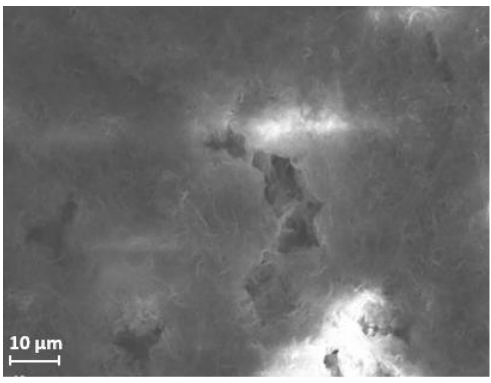

(a)

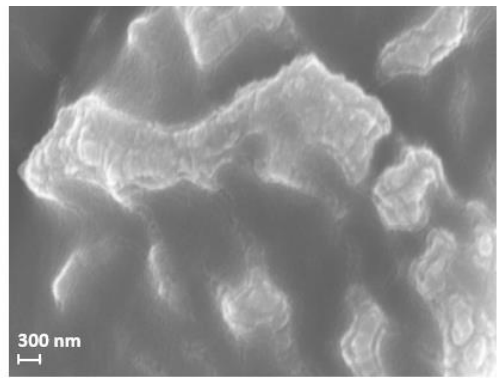

(b)

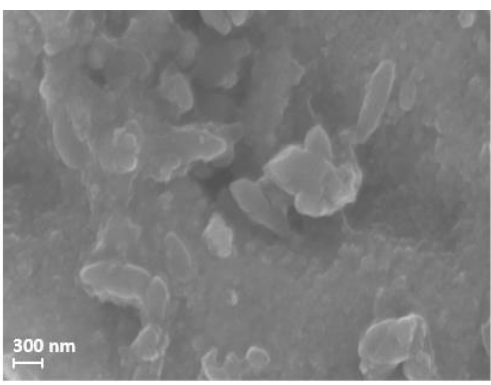

(c)

Figure 5. SEM photos of the $\mathrm{ZnO}$ layer surface heated at: (a) $100^{\circ} \mathrm{C}$, (b) $300^{\circ} \mathrm{C}$, and (c) $500^{\circ} \mathrm{C}$.

At a temperature of $100^{\circ} \mathrm{C}$ (Fig. 5a), the layer is still coarse and porous, with a pore size of approximately $6-8 \mu \mathrm{m}$. This is because the layer still contains water molecules and solvents that have not completely evaporated at this temperature. When the layer is heated at $300{ }^{\circ} \mathrm{C}$ (pre-heating), the remaining organic matter can evaporate completely, and $\mathrm{ZnO}$ grains begin to grow (Fig. 5b), but the distance between the particles is still relatively large. When the $\mathrm{ZnO}$ layer is heated at $500{ }^{\circ} \mathrm{C}$ (Fig. 5c), the atoms in the existing grains receive sufficient driving force energy to diffuse to form new, larger grains. As a result of this inter-grain diffusion, necking will be formed, resulting in the shrinking of the boundary between grains and porosity (Fig. 5c). The average grain size at this temperature is about $300 \mathrm{~nm}$.

To this end, the morphology and crystal structure of the $\mathrm{ZnO}$ layer made by the sol-gel process is influenced by the solvent, pre-heating and post-heating temperatures, sol concentration, substrate, and coating process (Habibi \& Khaledi Sardashti, 2008). The ZnO layer's nucleation thermodynamics and crystal growth showed a transformation from an amorphous to crystalline state. The growth of crystals with the dominant c-axis orientation depends on the surface energy of the layer and the glass substrate and the interfacial energy between them. In crystal growth, the growing fields depend on the loss of slow-growing fields, with lower surface energies.

In addition to heat treatment, the morphology and thickness of the $\mathrm{ZnO}$ layer are also affected by the spin coating speed. Figure 6 shows the surface morphology of the coated layer at 1500, 2000, and $2500 \mathrm{rpm}$. 


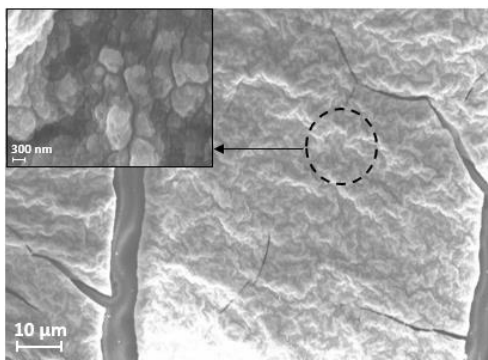

(a)

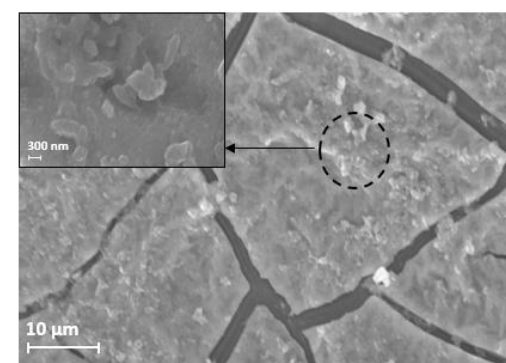

(b)

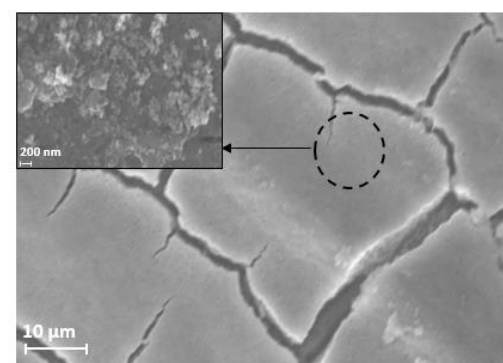

(c)

Figure 6. SEM photos of the $\mathrm{ZnO}$ layer surface coated with variations in rotation speed: (a) $1500 \mathrm{rpm}$, (b) $2000 \mathrm{rpm}$, and (c) $2500 \mathrm{rpm}$.

Based on Figure 6, it can be seen that the higher the rotation speed, the smoother the coating obtained, with smaller average grain size. The $\mathrm{ZnO}$ layer coated at 1500 and $2000 \mathrm{rpm}$ has similar average grain size of $300 \mathrm{~nm}$, while the $\mathrm{ZnO}$ layer coated at $2500 \mathrm{rpm}$ has an average grain size of $100 \mathrm{~nm}$. The results are consistent with previous studies that reported that the higher the rotational speed used to make the ZnO layer, the smaller of grain size produced (Ilican et al., 2008). The cross-sectional analysis of the coated $\mathrm{ZnO}$ layer with variations in rotational speed is presented in Figure 7.

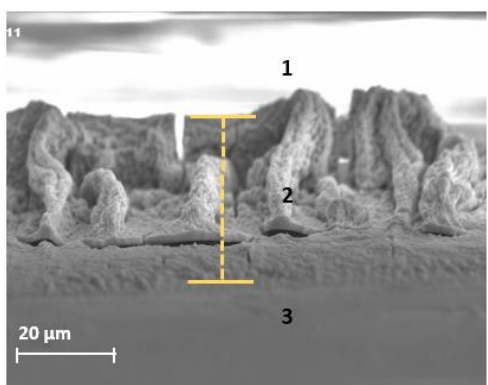

(a)

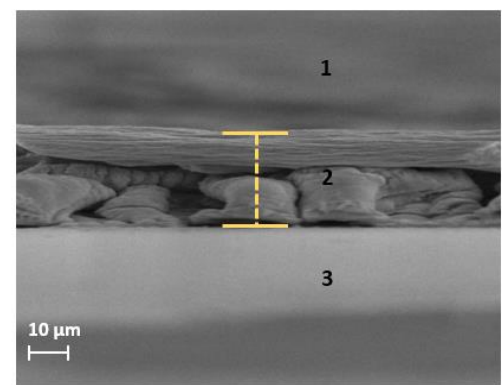

(b)

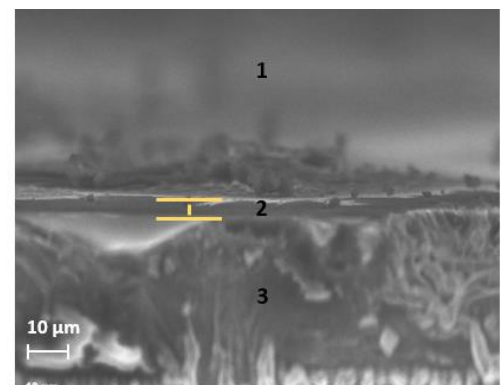

(c)

Figure 7. Cross-section of the coated $\mathrm{ZnO}$ layer with variations in rotational speed: (a) $1500 \mathrm{rpm}$, (b) $2000 \mathrm{rpm}$, and (c) $2500 \mathrm{rpm}$. (1 = air, 2 = ZnO layer thickness, $3=$ substrate)

The results show that the thickness of the $\mathrm{ZnO}$ layer coated with $1500 \mathrm{rpm}$ rotation is about $30 \mu \mathrm{m}$ (Fig. 7a), while the layer coated with $2000 \mathrm{rpm}$ rotation is about $20 \mu \mathrm{m}$ (Fig. 7b), $2500 \mathrm{rpm}$ at about $5 \mu \mathrm{m}$ (Fig. 7c). Therefore it is confirmed that the thickness of the $\mathrm{ZnO}$ layer gets thinner as the rotation speed increases. In forming a coating on the substrate, it takes a large enough centrifugal speed to distribute the gel over the entire surface and remove the excess gel to the outside of the substrate. If the rotational speed is increased, the previously attached gel will be thrown out of the substrate, and the layer will thin out, or it can also disappear. This is because the binding force between the substrate and the gel is not strong enough to withstand the centrifugal force, which is too high. So, the faster the coating rotation, the more gel will leave the substrate so that the resulting layer is thinner.

From the results in Figure 6, although the layer looks smooth, most of the areas in the layer have many micron-sized cracks. These cracks are caused by the uneven heating rate on the surface of the coating layer and the different thermal coefficient between the substrate and the coating layer. Cracks also occur in the area between the 
layer and the substrate (Fig. 6). Based on the cross-sectional photo of the $\mathrm{ZnO}$ layer (Fig. 7), it can be seen that the layer is not completely attached to the substrate. This condition makes the coating to peel off easily when exposed to scratches or friction from the outside. Cracks can also be seen from the EDX results (see Fig. 8). From the Figure we also see existence of $\mathrm{Ca}(0.98 \% \mathrm{wt})$ in the cracks, that originates from the substrate (from XRF results). Although the Ca content is small, this still indicates that the cracks are intense they penetrate the $\mathrm{ZnO}$ layer. Based on the Figure 8, it is estimated that the thickness of the $\mathrm{ZnO}$ layer formed with heating at $500{ }^{\circ} \mathrm{C}$ is about 5 $\mu \mathrm{m}$ to $20 \mu \mathrm{m}$.

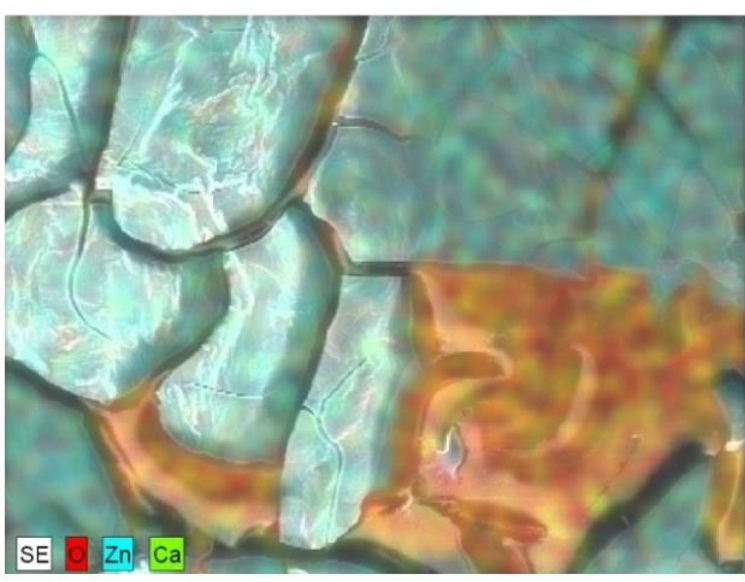

(a)

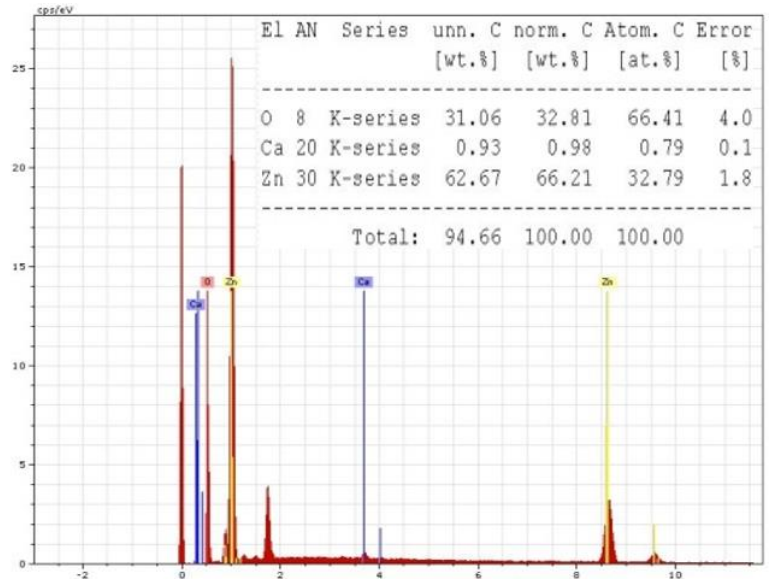

(b)

Figure 8. EDX results of $\mathrm{ZnO}$ layer on a glass substrate: (a) surface topography, and (b) elemental content.

Microcracks may occur on the ceramic coating surface with the cracks spreading along the grain boundaries (Sakka, 2018). This phenomena happens because the layer and the substrate have a huge difference in the coefficient of thermal expansion. The spread of microcracks along the grain boundaries is formed before the crystallization process. These microcracks can be prevented by equalizing the coefficient of thermal expansion $(\alpha)$ between the coating and the substrate. For example BaTiO3 $(\alpha=140 \mathrm{x}$ $\left.10^{-7} \mathrm{~K}^{-1}\right)$, the layer has microcracks when deposited on a SiO2 glass substrate $(\alpha=5 \mathrm{x}$ $\left.10^{-7} \mathrm{~K}^{-1}\right)$, but BaTiO3 has no microcracks on a single crystal substrate of $\mathrm{MgO}(\alpha=135$ $\left.\times 10^{-7} \mathrm{~K}^{-1}\right)($ Sakka, 2018). Microcracks can occur during the heating process at low temperatures $\left(100^{\circ} \mathrm{C}-400^{\circ} \mathrm{C}\right)$. In another study (Kozuka \& Hirano, 2000) reported that in the production of the titania layer, the crystal structure appears at a temperature of $500^{\circ} \mathrm{C}$, while cracks appear at temperatures below it. This means that the crack occurs before the crystallization process.

Microcracks can also occur due to variations in the thickness of the gel layer. In the titania layer made with variations in thickness, the thicker layer is obtained, which tends to crack at low temperatures (Kozuka \& Hirano, 2000). This happens because the thickness affects the occurrence of intrinsic stress during the heating process. The crack formation also depends on the heating rate. Cracks appear at higher temperatures when the coating is heated at a low heating rate. At low heating, the rate will produce a smaller porosity. This indicates that the low heating rate allows sufficient time for the coating to solidify during heating resulting in high tensile stresses in the substrate plane. 


\section{CONCLUSION}

The $\mathrm{ZnO}$ layer was successfully deposited on a glass substrate by heat treatment at $300{ }^{\circ} \mathrm{C}$ and $500{ }^{\circ} \mathrm{C}$. At a heating temperature of $100^{\circ} \mathrm{C}$, the $\mathrm{ZnO}$ structure has not yet been formed, and when the heating temperature is $300{ }^{\circ} \mathrm{C}$, crystals have started to form but have not been oriented perfectly. ZnO crystals are perfectly oriented at 500 ${ }^{\circ} \mathrm{C}$. XRD results show that the higher heating temperature has resulted in higher diffraction peak intensity. At a heating temperature of $300^{\circ} \mathrm{C}$ crystals are formed but are not yet perfectly oriented while at $500{ }^{\circ} \mathrm{C}$ they are. On the other hand, higher spin coating rotation speed gives rise to lower intensity of diffraction peak. The $\mathrm{ZnO}$ crystallization is easier to form in the coating process with a lower rotation $(1500 \mathrm{rpm})$. Interestingly, the thin layer is stable over time where there is no significant change in each sample, both in terms of intensity and width of the $\mathrm{ZnO}$ crystal peak. The results indicate that gel precursor aged less than two days can form $\mathrm{ZnO}$ crystals. SEM results show that the surface morphology of the $\mathrm{ZnO}$ layer heated at $500{ }^{\circ} \mathrm{C}$ has an average grain size of $300 \mathrm{~nm}$. The cross-sectional results of SEM show that the higher the rotation speed, the thinner the resulting $\mathrm{ZnO}$ layer, where the thickness of the resulting layer is on the order of $>5 \mu \mathrm{m}$.

\section{RECOMMENDATION}

The XRD results of the $\mathrm{ZnO}$ layer deposited on the glass substrate were all polycrystalline in structure. Efforts to make $\mathrm{ZnO}$ layer single crystal must be continued, by proper selection of substrate and higher post-heating. In addition, the SEM results show that the surface morphology of the $\mathrm{ZnO}$ layer is not homogeneous, there are many cracks and the size is still thick. For this reason, it is necessary to carry out more in-depth experiments in terms of the use of appropriate concentrations, speeds, and rotation times, as well as the selection of a substrate that has a heat capacity and plane orientation in accordance with the $\mathrm{ZnO}$ layer, for example alumina ceramic material.

\section{ACKNOWLEDGMENT}

This research received no specific grant from any funding agency in the public, commercial, or not for profit sectors.

\section{REFERENCES}

Abd-Ellah, M., Moghimi, N., Zhang, L., Thomas, Joseph. P., McGillivray, D., Srivastava, S., \& Leung, K. T. (2016). Plasmonic gold nanoparticles for ZnOnanotube photoanodes in dye-sensitized solar cell application. Nanoscale, 8(3), 1658-1664. https://doi.org/10.1039/C5NR08029K

Cheng, Z., Zhang, J., \& Kronmüller, H. (2003). Magnetically soft phase in magnetization reversal processes of nanocomposite Sm 2 Fe 15 Ga 2 C x / a - Fe permanent magnetic materials. Physical Review B, 68(14), 144417. https:/ / doi.org/10.1103/PhysRevB.68.144417

Çopuroğlu, M., Koh, L. H. K., O’Brien, S., \& Crean, G. M. (2009). Comparative characterisation of zinc oxide thin films prepared from zinc acetate with or without water of hydration via the sol-gel method. Journal of Sol-Gel Science and Technology, 52(3), 432-438. https:/ / doi.org/10.1007/s10971-009-2016-0

Daiko, Y., Sakamoto, H., Katagiri, K., Muto, H., Sakai, M., \& Matsuda, A. (2008). Deposition of Ultrathin Nafion Layers on Sol-Gel-Derived Phenylsilsesquioxane 
Particles via Layer-by-Layer Assembly. Journal of The Electrochemical Society, 155(5), B479. https:/ / doi.org/10.1149/1.2885101

Djurišić, A. B., Ng, A. M. C., \& Chen, X. Y. (2010). ZnO nanostructures for optoelectronics: Material properties and device applications. Progress in Quantum Electronics, 34(4), 191-259. https://doi.org/10.1016/j.pquantelec.2010.04.001

Fathollahi, V., \& Amini, M. M. (2001). Sol-gel preparation of highly oriented galliumdoped zinc oxide thin films. Materials Letters, 50(4), 235-239. https:/ / doi.org/10.1016/S0167-577X(01)00231-2

Greene, J. E. (2017). Review Article: Tracing the recorded history of thin-film sputter deposition: From the 1800s to 2017. Journal of Vacuum Science E Technology A: Vacuum, Surfaces, and Films, 35(5), 05C204. https://doi.org/10.1116/1.4998940

Habibi, M. H., \& Khaledi Sardashti, M. (2008). Structure and morphology of nanostructured zinc oxide thin films Prepared by dip-vs. Spin-coating methods. Journal of the Iranian Chemical Society, 5(4), 603-609. https://doi.org/10.1007/BF03246140

Ilican, S., Caglar, Y., \& Caglar, M. (2008). Preparation and Characterization Of ZnO Thin Films Deposited By Sol-Gel Spin Coating Method. Journal of Optoelectronics and Advanced Materials, 10(10), 2578-2583.

Jittiarporn, P., Badilescu, S., Al Sawafta, M. N., Sikong, L., \& Truong, V.-V. (2017). Electrochromic properties of sol-gel prepared hybrid transition metal oxides A short review. Journal of Science: Advanced Materials and Devices, 2(3), 286-300. https:/ / doi.org/10.1016/j.jsamd.2017.08.005

Kawamura, G., Sato, S., Muto, H., Sakai, M., Lim, P. B., Watanabe, K., Inoue, M., \& Matsuda, A. (2010). AgBr nanocrystal-dispersed silsesquioxane-titania hybrid films for holographic materials. Materials Letters, 64(23), 2648-2651. https://doi.org/10.1016/j.matlet.2010.08.068

Khan, M. I., Bhatti, K. A., Qindeel, R., Alonizan, N., \& Althobaiti, H. S. (2017). Characterizations of multilayer $\mathrm{ZnO}$ thin films deposited by sol-gel spin coating technique. Results in Physics, 7, 651-655. https://doi.org/10.1016/j.rinp.2016.12.029

Kim, S. W., Nam, K. W., Seo, D. H., Hong, J., Kim, K., Gwon, H., \& Kang, K. (2012). Energy storage in composites of a redox couple host and a lithium ion host. Nano Today, 7(3), 168-173. https:/ / doi.org/10.1016/j.nantod.2012.04.004

Kozuka, H., \& Hirano, M. (2000). Radiative Striations and Surface Roughness of Alkoxide-Derived Spin Coating Films. Journal of Sol-Gel Science and Technology, 19(1/3), 501-504. https:/ / doi.org/10.1023/ A:1008772102546

Maldonado, A., Tirado-Guerra, S., Cázares, J. M., \& Olvera, M. de la L. (2010). Physical and sensing properties of ZnO:F:Al thin films deposited by sol-gel. Thin Solid Films, 518(7), 1815-1820. https:// doi.org/10.1016/j.tsf.2009.09.039

Mandal, S., Goswami, M. L. N., Das, K., Dhar, A., \& Ray, S. K. (2008). Temperature dependent photoluminescence characteristics of nanocrystalline $\mathrm{ZnO}$ films grown by sol-gel technique. Thin Solid Films, 516(23), 8702-8706. https:/ / doi.org/10.1016/j.tsf.2008.05.016

Matsuda, A., \& Kawamura, G. (2016). Sol-Gel Nano-/Micropatterning Process. In L. Klein, M. Aparicio, \& A. Jitianu (Eds.), Handbook of Sol-Gel Science and Technology (pp. 1-28). Springer International Publishing. https://doi.org/10.1007/978-3319-19454-7_81-1 
Mironyuk, I., Mykytyn, I., Vasylyeva, H., \& Savka, K. (2020). Sodium-modified mesoporous TiO2: Sol-gel synthesis, characterization and adsorption activity toward heavy metal cations. Journal of Molecular Liquids, 316, 113840. https:/ / doi.org/10.1016/j.molliq.2020.113840

Mosa, J., \& Aparicio, M. (2020). Sol-Gel Synthesis of Nanocrystalline Mesoporous Li4Ti5O12 Thin-Films as Anodes for Li-Ion Microbatteries. Nanomaterials, 10(7), 1369. https://doi.org/10.3390/nano10071369

Muchuweni, E., Sathiaraj, T. S., \& Nyakotyo, H. (2017). Synthesis and characterization of zinc oxide thin films for optoelectronic applications. Heliyon, 3(4), e00285. https://doi.org/10.1016/j.heliyon.2017.e00285

Nbelayim, P., Ashida, Y., Maegawa, K., Kawamura, G., Muto, H., \& Matsuda, A. (2020). Preparation and Characterization of Stable and Active Pt@TiO 2 CoreShell Nanoparticles as Electrocatalyst for Application in PEMFCs. ACS Applied Energy Materials, 3(4), 3269-3281. https:/ / doi.org/10.1021/acsaem.9b02169

Nbelayim, P., Kawamura, G., Abdel-Galeil, M. M., Tan, W. K., Wei, X., Muto, H., \& Matsuda, A. (2018). Effects of multi-sized and -shaped $\mathrm{Ag} @ \mathrm{TiO}_{2}$ nanoparticles on the performance of plasmonic dye-sensitized solar cells. Journal of the Ceramic Society of Japan, 126(3), 139-151. https:/ / doi.org/10.2109/jcersj2.17203

Nbelayim, P., Kawamura, G., Kian Tan, W., Muto, H., \& Matsuda, A. (2017). Systematic characterization of the effect of Ag@TiO2 nanoparticles on the performance of plasmonic dye-sensitized solar cells. Scientific Reports, 7(1), 15690. https:/ / doi.org/10.1038/s41598-017-15541-z

Nisticò, R., Scalarone, D., \& Magnacca, G. (2017). Sol-gel chemistry, templating and spin-coating deposition: A combined approach to control in a simple way the porosity of inorganic thin films/coatings. Microporous and Mesoporous Materials, 248, 18-29. https:/ / doi.org/10.1016/j.micromeso.2017.04.017

Prasada Rao, T., Santhosh Kumar, M. C., Safarulla, A., Ganesan, V., Barman, S. R., \& Sanjeeviraja, C. (2010). Physical properties of ZnO thin films deposited at various substrate temperatures using spray pyrolysis. Physica B: Condensed Matter, 405(9), 2226-2231. https:/ / doi.org/10.1016/j.physb.2010.02.016

Qin, H., Guo, W., Huang, X., Gao, P., \& Xiao, H. (2020). Preparation of yttria-stabilized $\mathrm{ZrO} 2$ nanofiltration membrane by reverse micelles-mediated sol-gel process and its application in pesticide wastewater treatment. Journal of the European Ceramic Society, 40(1), 145-154. https:/ / doi.org/10.1016/j.jeurceramsoc.2019.09.023

Raoufi, D., \& Raoufi, T. (2009). The effect of heat treatment on the physical properties of sol-gel derived ZnO thin films. Applied Surface Science, 255(11), 5812-5817. https:// doi.org/10.1016/j.apsusc.2009.01.010

Rwenyagila, E. R., Agyei-Tuffour, B., Zebaze Kana, M. G., Akin-Ojo, O., \& Soboyejo, W. O. (2014). Optical properties of $\mathrm{ZnO} / \mathrm{Al} / \mathrm{ZnO}$ multilayer films for large area transparent electrodes. Journal of Materials Research, 29(24), 2912-2920. https:/ / doi.org/10.1557/jmr.2014.298

Sakka, S. (2018). Sol-Gel Formation of Bulk Glasses. In L. Klein, M. Aparicio, \& A. Jitianu (Eds.), Handbook of Sol-Gel Science and Technology (pp. 233-256). Springer International Publishing. https://doi.org/10.1007/978-3-319-32101-1_6

Shi, S., Xu, C., Wang, X., Xie, Y., Wang, Y., Dong, Q., Zhu, L., Zhang, G., \& Xu, D. (2020). Electrospinning fabrication of flexible Fe3O4 fibers by sol-gel method with high saturation magnetization for heavy metal adsorption. Materials $\mathcal{E}$ Design, 186, 108298. https:/ / doi.org/10.1016/j.matdes.2019.108298 
Sivaramakrishnan, K., \& Alford, T. L. (2010). Conduction and transmission analysis in gold nanolayers embedded in zinc oxide for flexible electronics. Applied Physics Letters, 96(20), 201109. https:/ / doi.org/10.1063/1.3435467

Soo, M. T., Kawamura, G., Muto, H., Matsuda, A., Lockman, Z., \& Cheong, K. Y. (2013a). Design of hierarchically meso-macroporous tetragonal ZrO2 thin films with tunable thickness by spin-coating via sol-gel template route. Microporous and Mesoporous Materials, 167, 198-206. https:/ / doi.org/10.1016/j.micromeso.2012.09.010

Soo, M. T., Kawamura, G., Muto, H., Matsuda, A., Lockman, Z., \& Cheong, K. Y. (2013b). Fabrication of well-crystallized mesoporous $\mathrm{ZrO} 2$ thin films via Pluronic P123 templated sol-gel route. Ceramics International, 39, S437-S440. https://doi.org/10.1016/j.ceramint.2012.10.109

Suwanboon, S., Tanattha, R., \& Tanakorn, R. (2008). Fabrication and properties of nanocrystalline zinc oxide thin film prepared by sol-gel method. Songklanakarin Journal of Science and Technology, 30(1), 65-69.

Tadanaga, K., Fujii, T., Matsuda, A., Minami, T., \& Tatsumisago, M. (2004). Micropatterning of Sol-Gel Derived Thin Films Using Hydrophobic-Hydrophilic Patterned Surface. Journal of Sol-Gel Science and Technology, 31(1-3), 299-302. https:/ / doi.org/10.1023/B:JSST.0000048007.43110.fa

Takahashi, M. (2018). Responsive and Adaptive Micro Wrinkles on Organic-Inorganic Hybrid Materials. The Chemical Record, 18(7-8), 1222-1231. https:/ / doi.org/10.1002/tcr.201800007

Takahashi, M., Suzuki, K., Tokudome, Y., Malfatti, L., \& Innocenzi, P. (2014). Responsive microstructures on organic-inorganic hybrid films. Journal of Sol-Gel Science and Technology, 70(2), 272-277. https://doi.org/10.1007/s10971-0143301-0

Tan, W. K., Ito, T., Kawamura, G., Muto, H., Lockman, Z., \& Matsuda, A. (2017). Controlled facile fabrication of plasmonic enhanced Au-decorated $\mathrm{ZnO}$ nanowire arrays dye-sensitized solar cells. Materials Today Communications, 13, 354-358. https:// doi.org/10.1016/j.mtcomm.2017.11.004

Tan, W. K., Muto, H., Ito, T., Kawamura, G., Lockman, Z., \& Matsuda, A. (2020). Facile Fabrication of Plasmonic Enhanced Noble-Metal-Decorated ZnO Nanowire Arrays for Dye-Sensitized Solar Cells. Journal of Nanoscience and Nanotechnology, 20(1), 359-366. https:// doi.org/10.1166/jnn.2020.17223

Tan, W. K., Muto, H., Kawamura, G., Lockman, Z., \& Matsuda, A. (2021). Nanomaterial Fabrication through the Modification of Sol-Gel Derived Coatings. Nanomaterials, 11(1), 181. https:/ / doi.org/10.3390/nano11010181

Tawa, S., Sato, Y., Orikasa, Y., Matsumoto, K., \& Hagiwara, R. (2019). Lithium fluoride/iron difluoride composite prepared by a fluorolytic sol-gel method: Its electrochemical behavior and charge-discharge mechanism as a cathode material for lithium secondary batteries. Journal of Power Sources, 412, 180-188. https:/ / doi.org/10.1016/j.jpowsour.2018.11.046

Toe, M. Z., Pung, S. Y., Yaacob, K. A., Matsuda, A., Tan, W. K., \& Han, S. S. (2020). Effect of $\mathrm{TiO} 2$ sol on the conversion efficiency of $\mathrm{TiO} 2$ based dye-sensitized solar cell. Journal of Sol-Gel Science and Technology, 95(2), 439-446. https:/ / doi.org/10.1007/s10971-020-05325-9

Torres Delgado, G., Zúñiga Romero, C. I., Mayén Hernández, S. A., Castanedo Pérez, R., \& Zelaya Angel, O. (2009). Optical and structural properties of the sol-gel- 
prepared $\mathrm{ZnO}$ thin films and their effect on the photocatalytic activity. Solar Energy Materials and Solar Cells, 93(1), 55-59. https:/ / doi.org/10.1016/j.solmat.2008.03.020

Valverde-Aguilar, G., \& Manríquez Zepeda, J. L. (2015). Photoluminescence and photoconductivity studies on amorphous and crystalline $\mathrm{ZnO}$ thin films obtained by sol-gel method. Applied Physics A, 118(4), 1305-1313. https:/ / doi.org/10.1007/s00339-014-8836-y

Xu, L., Shi, L., \& Li, X. (2009). Preparation of nanocone $\mathrm{ZnO}$ thin film and its aging effect of photoluminescence. Applied Surface Science, 255(11), 5957-5960. https://doi.org/10.1016/j.apsusc.2009.01.044

Zou, G., Chen, W., Liu, R., \& Xu, Z. (2007). Orientation enhancement of polycrystalline $\mathrm{ZnO}$ thin films through thermal oxidation of electrodeposited zinc metal. Materials Letters, $61(21)$ 4305-4308. https:/ / doi.org/10.1016/j.matlet.2007.01.092 